\title{
Effectiveness of Vintage Hormone Therapy as Alternative Androgen Deprivation Therapy for Non-metastatic Castration-resistant Prostate Cancer
}

\author{
HIROAKI IWAMOTO, HIROSHI KANO, TAKAFUMI SHIMADA, RENATO NAITO, \\ TOMOYUKI MAKINO, SUGURU KADAMOTO, HIROSHI YAEGASHI, KAZUYOSHI SHIGEHARA, \\ KOUJI IZUMI, YOSHIFUMI KADONOA and ATSUSHI MIZOKAMI \\ Department of Integrative Cancer Therapy and Urology, \\ Kanazawa University Graduate School of Medical Science, Kanazawa, Japan
}

\begin{abstract}
Background/Aim: Vintage hormone therapy for non-metastatic castration-resistant prostate cancer ( $n m C R P C)$ is not recommended under the current guidelines, but is widely practiced in Japan. This study assessed effectiveness of vintage hormone therapy as alternative androgen deprivation therapy (AADT) for treatment of $n m C R P C$. Patients and Methods: In this retrospective study we examined patients with $n m C R P C$ that received vintage hormone therapy as AADT between 1999 and 2018. Results: Of 53 patients with nmCRPC, 25 patients (47.2\%) had stage 1 nodal disease (N1) at diagnosis of nmCRPC. Prostate specific antigen (PSA) reduction rate $\geq 30 \%$ was observed in 32 patients $(72.7 \%)$. The median PSA nadir was 0.7 , and the duration of the response was 14.3 months. The median metastasis-free survival (MFS) for the entire patient population was 62.2 months, and the median overall survival (OS) was not reached. In the multivariate analysis, the duration of response in AADT>18 months was a predictor of prolonged OS. Conclusion: There is a certain number of nmCRPC patients who respond well to vintage hormone therapy as AADT. Further studies are expected to differentiate such cases.
\end{abstract}

This article is freely accessible online.

Correspondence to: Hiroaki Iwamoto, Department of Integrative Cancer Therapy and Urology, Graduate School of Medical Science, Kanazawa University, Takaramachi13-1, Kanazawa, Ishikawa 9208640, Japan. Tel: +81 762652393, Fax: +81 762344263, e-mail: hiroaki017@yahoo.co.jp

Key Words: Vintage hormone, alternative androgen deprivation therapy, non-metastatic castration-resistant prostate cancer, androgen receptor signalling-targeted agent.
Prostate cancer (PC) is the most common cancer in men, and it is a leading cause of cancer-related deaths in developed countries $(1,2)$. The development and widespread use of prostate-specific antigen (PSA) screening tests has contributed to the detection of early PC, reducing mortality from it $(3,4)$. Androgen deprivation therapy (ADT) is the mainstay of treatment for patients with advanced and locally-advanced PC. It is also one of the main treatment options following biochemical recurrence in patients with localized PC who have undergone local treatment, such as surgery or radiation (5). Most patients with PC initially show a favorable response to ADT. Nevertheless, failure of ADT is nearly unavoidable, and most $\mathrm{PC}$ progresses to castrationresistant PC (CRPC). Non-metastatic CRPC (nmCRPC) has no obvious metastases other than local lymph node metastasis, as determined by conventional imaging, and is clinically differentiated from metastatic CRPC (mCRPC) in therapeutic strategies. Patients with mCRPC, especially those with visceral metastases, have been found to have very poor prognosis $(6,7)$. Delaying the progression to $\mathrm{mCRPC}$ by treating for $\mathrm{nmCRPC}$ may be key to improving the prognosis of patients with PC. According to 2020 National Comprehensive Cancer Network Clinical Practice Guidelines in Oncology for Prostate Cancer, it is now a category 1 recommendation to use apalutamide, darolutamide, and enzalutamide for the treatment of nmCRPC (8). However, second-line (vintage) hormone therapy is still widely used as an alternative antiandrogen therapy (AADT) in Japan for men with nmCRPC (9). In this study, we retrospectively investigated the effect of vintage hormone therapy as AADT in patients with nmCRPC. Additionally, we examined prognostic factors.

\section{Patients and Methods}

Study design. In this study, 53 patients with nmCRPC that received vintage hormone therapy as AADT after failure of primary ADT at Kanazawa University Hospital between 1999 and 2018 were 
Table I. Patient characteristics in primary ADT.

\begin{tabular}{|c|c|}
\hline & Vintage hormone therapy \\
\hline $\mathrm{n}$ & 53 \\
\hline Median age at diagnosis of $\mathrm{PC}, \mathrm{yr}$ (range) & $72(55-86)$ \\
\hline $\begin{array}{l}\text { Median PSA at diagnosis of PC, } \mathrm{ng} / \mathrm{ml} \\
\text { (range) }\end{array}$ & $68.4(5.6-841.5)$ \\
\hline \multicolumn{2}{|l|}{ Histology } \\
\hline $\mathrm{GS} \leq 6$ & 1 \\
\hline $\mathrm{GS}=7$ & 13 \\
\hline $\mathrm{GS} \geq 8$ & 35 \\
\hline Unknown & 4 \\
\hline \multicolumn{2}{|l|}{$\mathrm{T}$ stage at diagnosis of $\mathrm{PC}$} \\
\hline$\leq \mathrm{T} 2$ & 14 \\
\hline$\geq \mathrm{T} 3$ & 28 \\
\hline $\mathrm{Tx}$ & 11 \\
\hline \multicolumn{2}{|l|}{$\mathrm{N}$ stage at diagnosis of $\mathrm{PC}$} \\
\hline No & 27 \\
\hline N1 & 22 \\
\hline $\mathrm{Nx}$ & 4 \\
\hline \multicolumn{2}{|l|}{ Primary localized treatment } \\
\hline CAB only & 28 \\
\hline Radiation & 20 \\
\hline Radical prostatectomy & 5 \\
\hline \multicolumn{2}{|l|}{ Castration } \\
\hline Leuprorelin & 43 \\
\hline Goserelin & 6 \\
\hline Degarelix & 4 \\
\hline \multicolumn{2}{|l|}{ Antiandrogen $\left(1^{\text {st }}\right)$} \\
\hline Bicaltamide & 41 \\
\hline Chlormadinone & 10 \\
\hline Estramustine & 1 \\
\hline Flutamide & 1 \\
\hline $\begin{array}{l}\text { Median PSA nadir value during } \\
\text { primary ADT, } \mathrm{ng} / \mathrm{ml} \text { (range) }\end{array}$ & $0.13(0.008-5.1)$ \\
\hline $\begin{array}{l}\text { Duration of response in primary } \\
\text { ADT, months (range) }\end{array}$ & $24.4(1.1-122.9)$ \\
\hline
\end{tabular}

ADT: Androgen-deprivation therapy; PC: prostate cancer; PSA: prostate-specific antigen; GS: Gleason score; CAB: combined androgen blockade; ARST: androgen receptor signaling-targeted agent.

included. All patients were histologically diagnosed with adenocarcinoma of the prostate, initially treated with combined androgen blockade, and showed disease progression following initial treatment. PSA failure after ADT was defined as a PSA level at least $2.0 \mathrm{ng} / \mathrm{ml}$ higher and a $25 \%$ rise from the nadir level, which was confirmed by a second PSA test at least 4 weeks later. Cases satisfying the above criteria were diagnosed as CRPC. Vintage hormonal agents included: i) bicalutamide, ii) flutamide, iii) chlormadinone, iv) estramustine, and v) ethinylestradiol. We retrospectively reviewed the charts of all the patients and analyzed the relevant data. The collected medical data included: i) age, ii) serum PSA level, iii) prostate biopsy pathology, iv) clinical stage, and v) treatment progress. The clinical stage was determined based on the 2017 TNM Classification of Malignant Tumors, $8^{\text {th }}$ Edition (10). Cancer staging used: i) computerized tomography (CT), ii) magnetic resonance imaging (MRI), and iii) bone scintigraphy. Imaging tests, such as CT and MRI, were performed at the time of
Table II. Patient characteristics in AADT.

\begin{tabular}{lc}
\hline & Vintage hormone therapy \\
\hline $\mathrm{n}$ & 53 \\
Median age at diagnosis of CRPC, & $76(58-90)$ \\
yr (range) & \\
$\mathrm{N}$ stage at diagnosis of CRPC & \\
$\mathrm{N} 0$ & 27 \\
$\mathrm{~N} 1$ & 25 \\
$\mathrm{Nx}$ & 1 \\
Median PSA nadir value during & $(0.008-13.198)$ \\
AADT, ng/ml (range) & \\
Comfirmed anti-androgen withdrawal & $22(41.5 \%)$ \\
syndrome, $\mathrm{n}(\%)$ & \\
Anti-androgen withdrawal response, $\mathrm{n}(\%)$ & $8(36.4 \%)$ \\
Antiandrogen (2nd) & 32 \\
Flutamide & 11 \\
Bicaltamide & 3 \\
Chlormadinone & 4 \\
Estramustine & 3 \\
Ethinylestradiol & \\
PSA reduction rate (\%) & \\
$\geq 30 \%$ & 32 \\
$<30 \%$ & 12 \\
$\geq 50 \%$ & 25 \\
$<50 \%$ & 19 \\
Unknown & 9 \\
Duration of response in AADT, months & \\
(range) & $14.3(1.1-118.3)$ \\
ARST (3rd) & \\
PSA reduction rate $\geq 50 \%$ & 9 \\
& \\
\hline & \\
&
\end{tabular}

AADT: Alternative androgen-deprivation therapy; CRPC: castrationresistant prostate cancer; PSA: prostate-specific antigen; ARST: androgen receptor signaling-targeted agent.

PC diagnosis and at the progression to CRPC. After that, the interval between subsequent imaging studies and all therapeutic decisions were at the discretion of each attending physician. Follow up was terminated on May 31, 2020. Survival was measured from the time of diagnosis of nmCRPC until death or the last follow up.

Statistical analysis. Metastasis-free survival (MFS) and overall survival (OS) were retrospectively analyzed using the Kaplan-Meier method. The Cox proportional hazard model was used for multivariate analyses. Log-rank tests were used for the comparison of the survival distributions. Statistical analyses were performed using SPSS software, version 25.0 (SPSS Inc., Chicago, IL, USA) and Prism 5 (GraphPad, San Diego, CA, USA). In all analyses, a $p$ Value of less than 0.05 indicated statistical significance. This study was approved by the institutional review board of Kanazawa University Hospital (2016-328).

\section{Results}

Patient characteristics for primary ADT. Patient characteristics for primary ADT are shown in Table I. The median age at PC diagnosis for the 53 patients who met the 
Table III. Univariate and multivariate analyses on MFS and OS from diagnosis of nmCRPC.

\begin{tabular}{|c|c|c|c|c|c|c|c|c|}
\hline & \multicolumn{4}{|c|}{ MFS from diagnosis of nmCRPC } & \multicolumn{4}{|c|}{ OS from diagnosis of nmCRPC } \\
\hline & \multicolumn{2}{|l|}{ Univariate } & \multicolumn{2}{|c|}{ Multivariate } & \multicolumn{2}{|c|}{ Univariate } & \multicolumn{2}{|c|}{ Multivariate } \\
\hline & $\operatorname{HR}(95 \% \mathrm{CI})$ & $p$-Value & $\operatorname{HR}(95 \% \mathrm{CI})$ & $p$-Value & HR $(95 \%$ CI $)$ & $p$-Value & HR $(95 \%$ CI $)$ & $p$-Value \\
\hline $\begin{array}{l}\text { T stage at diagnosis of } \mathrm{PC} \\
(\leq \mathrm{T} 2 \text { vs. } \geq \mathrm{T} 3)\end{array}$ & $1.03(0.44-2.44)$ & 0.94 & & & $1.66(0.46-6.05)$ & 0.44 & & \\
\hline $\begin{array}{l}\text { N stage at diagnosis of PC } \\
\text { (N0 vs. N1) }\end{array}$ & $0.98(0.44-2.16)$ & 0.96 & & & $0.99(0.34-2.86)$ & 0.99 & & \\
\hline Gleason score $(\leq 8 v s . \geq 9)$ & $1.93(0.85-4.38)$ & 0.12 & $1.37(0.37-5.04)$ & 0.63 & $1.83(0.57-5.85)$ & 0.31 & & \\
\hline AWS (Yes vs. No) & $1.04(0.35-3.08)$ & 0.94 & & & $1.42(0.26-7.78)$ & 0.69 & & \\
\hline $\begin{array}{l}\text { PSA nadir in primary ADT } \\
(<0.3 v s . \geq 0.3)\end{array}$ & $1.12(0.43-2.91)$ & 0.81 & & & $0.90(0.19-4.36)$ & 0.9 & & \\
\hline $\begin{array}{l}\text { Duration of response in primary } \\
\text { ADT ( } \geq 18 v s .<18 \text { months })\end{array}$ & $1.07(0.48-2.39)$ & 0.87 & & & $1.17(0.38-3.58)$ & 0.79 & & \\
\hline $\begin{array}{l}\text { Age at diagnosis of nmCRPC } \\
(<70 \mathrm{vs} . \geq 70 \mathrm{yr})\end{array}$ & $0.70(0.32-1.53)$ & 0.36 & & & $0.45(0.16-1.24)$ & 0.12 & & \\
\hline $\begin{array}{l}\text { T stage at diagnosis of CRPC } \\
(\leq \mathrm{T} 2 \text { vs. } \geq \mathrm{T} 3)\end{array}$ & $1.00(0.38-2.62)$ & 1 & & & $1.26(0.34-4.67)$ & 0.73 & & \\
\hline $\begin{array}{l}\mathrm{N} \text { stage at diagnosis of CRPC } \\
(\mathrm{N} 0 \text { vs. N1) }\end{array}$ & $1.26(0.59-2.71)$ & 0.55 & & & $1.51(0.52-4.39)$ & 0.45 & & \\
\hline $\begin{array}{l}\text { NLR at diagnosis of nmCRPC } \\
(<3 v s . \geq 3)\end{array}$ & $0.38(0.07-2.01)$ & 0.26 & & & $1.32(0.18-9.43)$ & 0.79 & & \\
\hline $\begin{array}{l}\text { PLR at diagnosis of nmCRPC } \\
(<160 v s . \geq 160 \mathrm{mg} / \mathrm{dl})\end{array}$ & $0.73(0.15-3.65)$ & 0.7 & & & $0.73(0.1-5.46)$ & 0.76 & & \\
\hline $\begin{array}{l}\text { LDH at diagnosis of nmCRPC } \\
(<200 v s . \geq 200 \mathrm{IU} / 1)\end{array}$ & $0.94(0.37-2.55)$ & 0.94 & & & $0.99(0.27-3.69)$ & 0.99 & & \\
\hline $\begin{array}{l}\text { PSA at diagnosis of nmCRPC } \\
(\leq 3 v s .>3 \mathrm{ng} / \mathrm{ml})\end{array}$ & $1.35(0.60-3.03)$ & 0.46 & & & $1.19(0.35-4.09)$ & 0.78 & & \\
\hline $\begin{array}{l}\text { Duration of response in alternative } \\
\text { ADT ( } \leq 18 v s .>18 \text { months) }\end{array}$ & $3.12(1.38-7.07)$ & 0.006 & $6.07(1.20-30.63)$ & 0.03 & $4.07(1.25-13.26)$ & 0.02 & $3.08(1.14-8.30)$ & 0.03 \\
\hline $\begin{array}{l}\text { PSA response rate in alternative } \\
\text { ADT }(\geq 30 v s .<30 \%)\end{array}$ & $4.72(1.37-16.24)$ & 0.014 & $3.06(0.85-11.02)$ & 0.09 & $3.10(1.33-7.22)$ & 0.01 & $2.10(0.87-5.11)$ & 0.1 \\
\hline
\end{tabular}

MFS: Metastasis-free survival; OS: overall survival; nmCRPC: non-metastatic castration-resistant prostate cancer; PC: prostate cancer; AWS : antiandrogen withdrawal syndrome; ADT: androgen-deprivation therapy; NLR: neutrophil-to-lymphocyte ratio; CRP: C-reactive protein; LDH: lactate dehydrogenase; PSA: prostate-specific antigen.

inclusion criteria was 72 years (range $=55-86$ years). Twenty-eight patients started treatment with combined androgen blockade (CAB) alone, and 25 patients received some form of curative treatment. The most commonly administered primary anti-androgen was bicalutamide (41 patients), followed by chlormadinone (10 patients). The median PSA nadir was $0.13 \mathrm{ng} / \mathrm{ml}$, and the duration of response was 24.4 months.

The patient characteristics for AADT. The patient characteristics for AADT are shown in Table II. The median age at diagnosis of nmCRPC was 76 years (range: 58-90). Twenty-five patients $(47.2 \%)$ had stage 1 nodal disease (N1) at diagnosis of nmCRPC. PSA reduction rate $\geq 30 \%$ was observed in 32 patients $(72.7 \%)$. PSA reduction rate $\geq 50 \%$ was observed in 25 patients $(56.8 \%)$. The median PSA nadir was $0.7 \mathrm{ng} / \mathrm{ml}$, and duration of response was 14.3 months.
Univariate and multivariate analyses on MFS and OS from diagnosis of $n m C R P C$. Table III shows the results of univariate and multivariate analyses on MFS and OS from the diagnosis of nmCRPC. Multivariate analysis showed that the duration of response in AADT less than 18 months (m) was a predictor of prolonged OS.

MFS and OS from the diagnosis of nmCRPC. Figure 1A and B shows MFS and OS from the diagnosis of nmCRPC, respectively. The median MFS for the entire patient population was 62.2 months, and the median OS was not reached. The median MFS for the duration response in AADT $>18$ m group was 93.0 months, and for the duration response in AADT $\leq 18 \mathrm{~m}$ group was 33.5 months $(p=0.009)$. The median OS in the duration response in AADT $>18 \mathrm{~m}$ group was not reached, while the median OS in the duration response in $\mathrm{AADT} \leq 18 \mathrm{~m}$ group was 75.1 months $(p=0.01)$. 

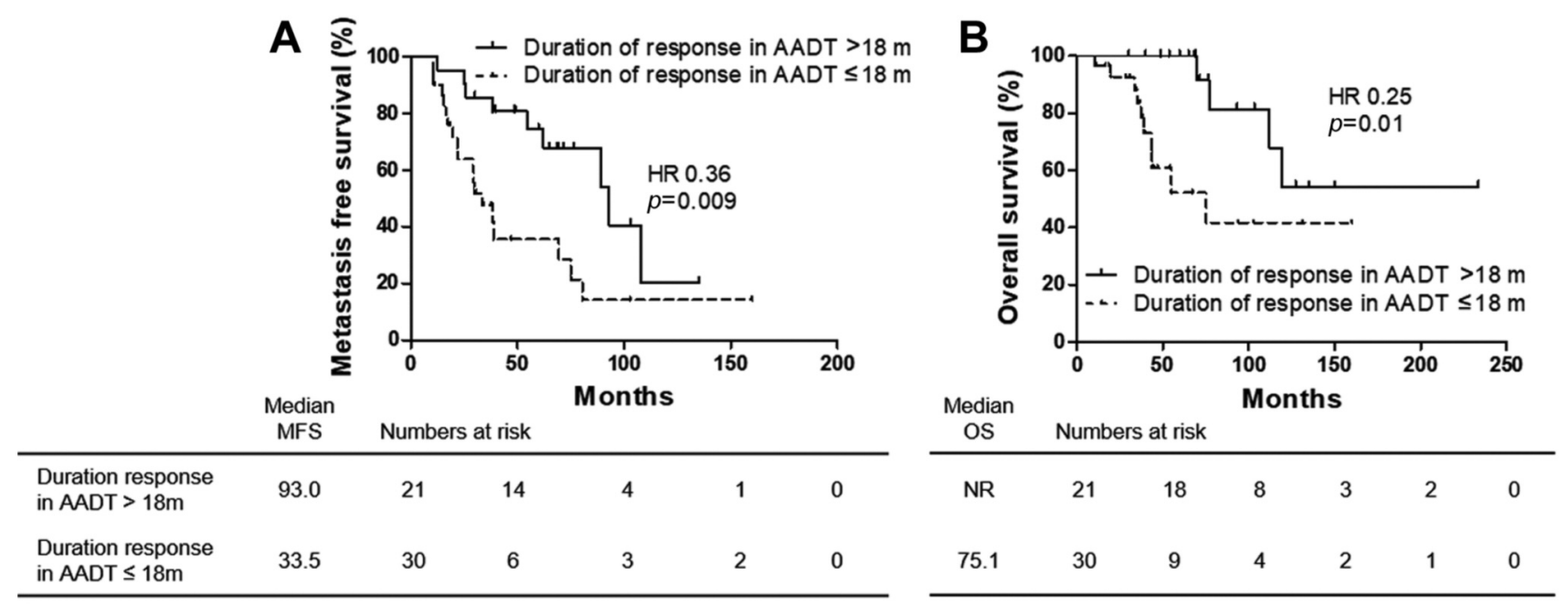

Figure 1. MFS and OS from the diagnosis of nmCRPC. MFS: Metastasis free survival; OS: overall survival; nmCRPC: non-metastatic castrationresistant prostate cancer; $A A D T$ : alternative androgen-deprivation therapy.

Survival was significantly prolonged in the duration response in AADT $>18$ m group.

\section{Discussion}

Prognosis for patients with mCRPC is generally poor, reported to be about 17-35 months $(7,11-14)$. The most important goal in the treatment of nmCRPC is to delay the progression to $\mathrm{mCRPC}$. In fact, it has been reported that there is a significant correlation between MFS and OS (15). Phase III PROSPER, SPARTAN, and ARAMIS trials in patients with nmCRPC have shown that enzalutamide, appartamide, or dalortamide can significantly prolong MFS compared to placebo (16-18). The median MFS in the above ARST group was 36.6-40.5 months, and the median MFS in the placebo group was 14.7-18.4 months. In Japan, vintage hormone therapy for patients with nmCRPC is still widely used as an AADT, but it is unclear whether it has the same effect as androgen receptor-signaling targeted agents (ARST) (9). If the PSA response is defined as a decrease in PSA of $50 \%$ or more, previous reports have shown that a PSA response was observed in $30.8 \%$ to $46 \%$ of CRPC patients who received vintage hormone therapy as AADT (19-26). In a study comparing vintage hormone therapy with ARST as an AADT, a report has described ARST or vintage hormone therapy to 103 patients with nmCRPC. The PSA response rate was $36.2 \%$ in the vintage hormone group and $62.5 \%$ in the ARST group (26). In a study comparing vintage hormone therapy to ARST as an AADT for 396 patients with CRPC, including 139 patients with nmCRPC, the PSA response rate was $31 \%$ in the bicalutamide group and $81 \%$ in the enzalutamide group $(p<0.001)(22)$. Even when limited to 139 patients with
nmCRPC, the PSA response rate was $42 \%$ in the flutamide group and $91 \%$ in the enzalutamide group, which was like the results for all patients with CRPC $(p<0.001)$. In another report of 55 patients with CRPC treated with enzalutamide or flutamide, including those with $\mathrm{nmCRPC}$, the PSA response rate was $30.8 \%$ in the flutamide group and $86.2 \%$ in the enzalutamide group $(p<0.01)(23)$. In the present study, the PSA response rate was $56.8 \%$, which was slightly lower compared to the rate of ARST-treated patients from previous reports. These results suggest that ARST may be more favorable for PSA reduction compared to the vintage hormone therapy. In an earlier study, the PSA response rate was similar for those who received enzalutamide as an AADT and those who received flutamide followed by enzalutamide as a $2^{\text {nd }}$ line treatment $(86.2 \%$ and $77.8 \%$, respectively, $p=0.69$ ) (23). In this study, the PSA response rate in the group receiving flutamide followed by ARST as a second line treatment was $77.8 \%$, which was a good result (Table II). From these results, it is possible that ARST for nmCRPC will result in a comparable PSA reduction with both 1st and 2nd line treatments. PSA decline is important, but it does not perfectly correlate with survival. In the two aforementioned studies, there was no significant difference in OS between the vintage and ARST groups $(23,26)$. In this study, the median OS was not reached even though the median observation period was as long as 48.5 months, which was a good result compared to the past ARST-administered group $(23,26)$. From previous reports, no significant difference in OS was observed between the vintage and ARST groups, suggesting that there must be a certain number of cases in which vintage hormone therapy can be effective as an AADT. It would be valuable, from a medical economic point of view, to 
distinguish between cases in which vintage hormone therapy is effective as an AADT for nmCRPC. In the multivariate analysis we examined the factors that prolong MFS and OS from the diagnosis of nmCRPC, and found that the duration response in $\mathrm{AADT}>18 \mathrm{~m}$ was a predictor of prognosis. If vintage hormone therapy can highlight the cases in which the duration response in AADT $>18 \mathrm{~m}$ can be expected, it may be possible to effectively use vintage hormones while retaining ARST as an option. Larger prospective studies are required in the future to identify cases in which vintage hormone therapy may be beneficial. Cases with a PSA nadir value in primary $\mathrm{ADT}>1 \mathrm{ng} / \mathrm{ml}$ and a time to PSA nadir during primary ADT $>1$ year have been reported to be less effective when vintage hormone therapy is administered as AADT, which may assist in case selection (27). Additional useful information for case selection could be: i) a PSA decrease of less than $97 \%$ after 3 months of vintage hormone therapy for metastatic hormone-sensitive prostate cancer (mHSPC) as a predictor of poor prognosis, and ii) vintage hormone therapy for patients with nmCRPC with short PSA doubling time (PSADT) also associated with poor prognosis $(28,29)$.

There are several limitations in the current study. It is a retrospective comparative study with a short observation period involving a small number of patients, all of whom are Japanese. Furthermore, PC treatment and the interval between imaging assessment are at the discretion of the attending physician.

In conclusion, there are a certain number of patients who respond well to vintage hormone therapy as AADT for nmCRPC. It is hoped that further studies will be able to distinguish such cases.

\section{Conflicts of Interest}

All Authors declare that there are no potential conflicts of interest relevant to this article.

\section{Authors' Contributions}

HI designed the experiments. HI, HK, TS, RN, TM, SK, HY, SK, KI, and YK collected clinical data. HI, RN, TM, SK, KI and AM analyzed the data. HI, KI, and AM drafted and revised the manuscript. All authors read and approved the final version of the manuscript

\section{References}

1 Siegel RL, Miller KD and Jemal A: Cancer statistics, 2019. CA Cancer J Clin 69(1): 7-34, 2019. PMID: 30620402. DOI: 10.3322/caac. 21551

2 Torre LA, Bray F, Siegel RL, Ferlay J, Lortet-Tieulent J and Jemal A: Global cancer statistics, 2012. CA Cancer J Clin 65(2): 87-108, 2015. PMID: 25651787. DOI: 10.3322/caac.21262

3 Byers T, Barrera E, Fontham ET, Newman LA, Runowicz CD, Sener SF, Thun MJ, Winborn S and Wender RC: A midpoint assessment of the american cancer society challenge goal to halve the u.S. Cancer mortality rates between the years 1990 and 2015. Cancer 107(2): 396-405, 2006. PMID: 16770789. DOI: $10.1002 /$ cncr. 21990

4 Schroder FH, Hugosson J, Roobol MJ, Tammela TL, Ciatto S, Nelen V, Kwiatkowski M, Lujan M, Lilja H, Zappa M, Denis LJ, Recker F, Paez A, Maattanen L, Bangma CH, Aus G, Carlsson S, Villers A, Rebillard X, van der Kwast T, Kujala PM, Blijenberg BG, Stenman UH, Huber A, Taari K, Hakama M, Moss SM, de Koning HJ and Auvinen A: Prostate-cancer mortality at 11 years of follow-up. N Engl J Med 366(11): 981990, 2012. PMID: 22417251. DOI: 10.1056/NEJMoa1113135

5 Sharifi N, Gulley JL and Dahut WL: An update on androgen deprivation therapy for prostate cancer. Endocr Relat Cancer 17(4): R305-315, 2010. PMID: 20861285. DOI: 10.1677/ERC10-0187

6 Halabi S, Kelly WK, Ma H, Zhou H, Solomon NC, Fizazi K, Tangen CM, Rosenthal M, Petrylak DP, Hussain M, Vogelzang NJ, Thompson IM, Chi KN, de Bono J, Armstrong AJ, Eisenberger MA, Fandi A, Li S, Araujo JC, Logothetis CJ, Quinn DI, Morris MJ, Higano CS, Tannock IF and Small EJ: Meta-analysis evaluating the impact of site of metastasis on overall survival in men with castration-resistant prostate cancer. J Clin Oncol 34(14): 1652-1659, 2016. PMID: 26951312. DOI: 10.1200/JCO.2015.65.7270

7 Iwamoto H, Izumi K, Shimada T, Kano H, Kadomoto S, Makino T, Naito R, Yaegashi H, Shigehara K, Kadono Y and Mizokami A: Androgen receptor signaling-targeted therapy and taxane chemotherapy induce visceral metastasis in castration-resistant prostate cancer. Prostate, 2020. PMID: 33047850. DOI: 10.1002/ pros. 24082

8 Network ${ }^{\circledR}$ NCC: Nccn clinical practice guidelines in prostate cancer. Version 2, 2020. Available at: https://www.nccn.org/ professionals/physician_gls/pdf/prostate.pdf [Last accessed on January 21 2021]

9 Mizokami A, Kadono Y, Kitagawa Y, Izumi K and Konaka H: Therapies for castration-resistant prostate cancer in a new era: The indication of vintage hormonal therapy, chemotherapy and the new medicines. Int J Urol 24(8): 566-572, 2017. PMID: 28577511. DOI: $10.1111 /$ iju.13372

10 Brierley JD, Gospodarowicz MK and Wittekind C: TNM classification of malignant tumours, $8^{\text {th }}$ edition. John Wiley $\&$ Sons, Ltd, 2017.

11 Beer TM, Armstrong AJ, Rathkopf DE, Loriot Y, Sternberg CN, Higano CS, Iversen P, Bhattacharya S, Carles J, Chowdhury S, Davis ID, de Bono JS, Evans CP, Fizazi K, Joshua AM, Kim CS, Kimura G, Mainwaring P, Mansbach H, Miller K, Noonberg SB, Perabo F, Phung D, Saad F, Scher HI, Taplin ME, Venner PM, Tombal B and Investigators P: Enzalutamide in metastatic prostate cancer before chemotherapy. N Engl J Med 371(5): 424433, 2014. PMID: 24881730. DOI: 10.1056/NEJMoa1405095

12 Petrylak DP, Tangen CM, Hussain MH, Lara PN, Jr., Jones JA, Taplin ME, Burch PA, Berry D, Moinpour C, Kohli M, Benson MC, Small EJ, Raghavan D and Crawford ED: Docetaxel and estramustine compared with mitoxantrone and prednisone for advanced refractory prostate cancer. N Engl J Med 351(15): 1513-1520, 2004. PMID: 15470214. DOI: 10.1056/NEJ Moa041318

13 Ryan CJ, Smith MR, Fizazi K, Saad F, Mulders PFA, Sternberg CN, Miller K, Logothetis CJ, Shore ND, Small EJ, Carles J, Flaig TW, Taplin M-E, Higano CS, de Souza P, de Bono JS, 
Griffin TW, De Porre P, Yu MK, Park YC, Li J, Kheoh T, Naini V, Molina A and Rathkopf DE: Abiraterone acetate plus prednisone versus placebo plus prednisone in chemotherapynaive men with metastatic castration-resistant prostate cancer (cou-aa-302): Final overall survival analysis of a randomised, double-blind, placebo-controlled phase 3 study. The Lancet Oncology 16(2): 152-160, 2015. PMID: 25601341. DOI: 10.1016/S1470-2045(14)71205-7

14 Tannock IF, de Wit R, Berry WR, Horti J, Pluzanska A, Chi KN, Oudard S, Theodore C, James ND, Turesson I, Rosenthal MA and Eisenberger MA: Docetaxel plus prednisone or mitoxantrone plus prednisone for advanced prostate cancer. N Engl J Med 351(15): 1502-1512, 2004. PMID: 15470213. DOI: 10.1056/ NEJMoa040720

15 Mori A, Hashimoto K, Koroki Y, Wu DB and Masumori N: The correlation between metastasis-free survival and overall survival in non-metastatic castration resistant prostate cancer patients from the medical data vision claims database in japan. Curr Med Res Opin 35(10): 1745-1750, 2019. PMID: 31084438. DOI: 10.1080/03007995.2019.1619543

16 Hussain M, Fizazi K, Saad F, Rathenborg P, Shore N, Ferreira U, Ivashchenko P, Demirhan E, Modelska K, Phung, Krivoshik A and Sternberg CN: Enzalutamide in men with nonmetastatic, castration-resistant prostate cancer. N Engl J Med 378(26): 2465-2474, 2018. PMID: 29949494. DOI: 10.1056/ NEJMoa1800536

17 Smith MR, Saad F, Chowdhury S, Oudard S, Hadaschik BA, Graff JN, Olmos D, Mainwaring PN, Lee JY, Uemura H, LopezGitlitz A, Trudel GC, Espina BM, Shu Y, Park YC, Rackoff WR, Yu MK, Small EJ and Investigators S: Apalutamide treatment and metastasis-free survival in prostate cancer. N Engl J Med 378(15): 1408-1418, 2018. PMID: 29420164. DOI: 10.1056/ NEJMoa1715546

18 Fizazi K, Shore N, Tammela TL, Ulys A, Vjaters E, Polyakov S, Jievaltas M, Luz M, Alekseev B, Kuss I, Kappeler C, Snapir A, Sarapohja $\mathrm{T}$ and Smith MR: Darolutamide in nonmetastatic, castration-resistant prostate cancer. N Engl J Med 380(13): 1235-1246, 2019. PMID: 30763142. DOI: 10.1056/ NEJMoa1815671

19 Suzuki H, Okihara K, Miyake H, Fujisawa M, Miyoshi S, Matsumoto T, Fujii M, Takihana Y, Usui T, Matsuda T, Ozono $\mathrm{S}$, Kumon H, Ichikawa T and Miki T: Alternative nonsteroidal antiandrogen therapy for advanced prostate cancer that relapsed after initial maximum androgen blockade. J Urol 180(3): 921927, 2008. PMID: 18635218. DOI: 10.1016/j.juro.2008.05.045

20 Okegawa $T$, Nutahara $\mathrm{K}$ and Higashihara E: Alternative antiandrogen therapy in patients with castration-resistant prostate cancer: A single-center experience. Int J Urol 17(11): 950-955, 2010. PMID: 20807265. DOI: 10.1111/j.1442-2042.2010.02620.x

21 Takada T, Ishizuya Y, Okada T, Ueda T, Inoue H and Hara T: Alternative antiandrogen therapy with flutamide in patients with castration-resistant prostate cancer: A single center experience. Hinyokika Kiyo 57(6): 291-295, 2011. PMID: 21795830.
22 Penson DF, Armstrong AJ, Concepcion R, Agarwal N, Olsson C, Karsh L, Dunshee C, Wang F, Wu K, Krivoshik A, Phung D and Higano CS: Enzalutamide versus bicalutamide in castrationresistant prostate cancer: The strive trial. J Clin Oncol 34(18): 2098-2106, 2016. PMID: 26811535. DOI: 10.1200/JCO. 2015.64 .9285

23 Iguchi T, Tamada S, Kato M, Yasuda S, Otoshi T, Hamada K, Yamasaki T and Nakatani T: Enzalutamide versus flutamide for castration-resistant prostate cancer after combined androgen blockade therapy with bicalutamide: A retrospective study. Int J Clin Oncol, 2019. PMID: 30741370. DOI: 10.1007/s10147-01901413-1

24 Nakano T, Kadono Y, Iwamoto H, Yaegashi H, Iijima M, Kawaguchi S, Nohara T, Shigehara K, Izumi K and Mizokami A: Therapeutic effect of ethinylestradiol in castration-resistant prostate cancer. Anticancer Res 40(4): 2291-2296, 2020. PMID: 32234928. DOI: 10.21873/anticanres.14194

25 Izumi K, Kadono Y, Shima T, Konaka H, Mizokami A, Koh E and Namiki M: Ethinylestradiol improves prostate-specific antigen levels in pretreated castration-resistant prostate cancer patients. Anticancer Res 30(12): 5201-5205, 2010. PMID: 21187513.

26 Miyake H, Matsushita Y, Watanabe H, Tamura K, Motoyama D, Ito T, Sugiyama T and Otsuka A: Comparative assessment of prognostic outcomes between first-generation antiandrogens and novel androgen-receptor-axis-targeted agents in patients with non-metastatic castration-resistant prostate cancer. Int J Clin Oncol 24(7): 842-847, 2019. PMID: 30739263. DOI: 10.1007/ s10147-019-01412-2

27 Fukuoka K, Teishima J, Nagamatsu H, Inoue S, Hayashi T, Mita K, Shigeta M, Kobayashi K, Kajiwara M, Kadonishi Y, Tacho T and Matsubara A: Predictors of poor response to first-generation anti-androgens as criteria for alternate treatments for patients with non-metastatic castration-resistant prostate cancer. Int Urol Nephrol 52(1): 77-85, 2020. PMID: 31552574. DOI: 10.1007/ s11255-019-02281-4

28 Miyake H, Watanabe K, Matsushita Y, Watanabe H, Tamura K, Motoyama D, Ito T, Sugiyama T and Otsuka A: Assessment of factors predicting disease progression in japanese patients with non-metastatic castration-resistant prostate cancer. Anticancer Res 40(2): 1101-1106, 2020. PMID: 32014960. DOI: 10.21873/ anticanres. 14049

29 Miyazawa Y, Sekine Y, Arai S, Oka D, Nakayama H, Syuto T, Nomura M, Koike H, Matsui H, Shibata Y and Suzuki K: Prognostic factors in hormone-sensitive prostate cancer patients treated with combined androgen blockade: A consecutive 15year study at a single japanese institute. In Vivo 35(1): 373-384, 2021. PMID: 33402486. DOI: 10.21873/invivo.12268

Received January 6, 2021

Revised January 20, 2021 Accepted January 21, 2021 